\title{
Perceptions on Socio-Economic Life in Oil Communities of Niger Delta, Nigeria
}

\author{
Salami Dada Kareem ${ }^{1}$;Oladipo Kolapo Sakiru ${ }^{2}$, ,Daskareem Vera Enoho ${ }^{1}$ \\ ${ }^{1}$ Contact Details:Department of Economics, Faculty of Social Sciences,Lagos State University, Ojo. Nigeria. \\ ${ }^{2}$ Department of Human Resource Development,Universiti Putra Malaysia.
}

\begin{abstract}
Socio-economic life enquiry in the Niger Delta region using the case of Burutu and Ogulagha is examined. Adopting a research survey technique, the following results were obtained. On average, about 18.3 per cent of the household heads earned regular income, with about 87.0percent not paying tax. Household income was indicated to be influenced by agriculture, education level and rate of environmental degradation. While the price of agricultural products seemed to be constant or rising slowly, annual sales and quality of agricultural produces have been decreasing. Interactions between the oil companies' staffs and the members of the community was said to be unfriendly. Massive youth unemployment in the community was found. Only 9.2 per cent of the household heads were working in the oil companies. The game would be win- win to both the oil companies and the indigenes if they choose to be friendly with one another. Rapid infrastructural development, environmental renewal and protection are the necessary remedial policy options.
\end{abstract}

Keywords: Household Head, ,Niger Delta, Oil Companies, Oil Spillage, , Socio-economic Life,

\section{Introduction}

Although, oil spillages in Nigeria are conventionally linked with causes such as equipment failure, poor maintenance of machineries and pipes carrying oil and human errors, illegal oil bunkering and the theft of petroleum products in Nigeria might have shoot up the volume of oil spillages. The Nigerian National Petroleum Corporation's estimate of reported cases of spillage between 1976 and 1996 showed that there were a total of 4,835 incidents resulting in the spillage of at least 2,446,322 barrels (102.7 million US gallons), of which an estimated 1,896,930 barrels (79.7 million US gallons-77 percent) were lost to the environment (1).The oil spill incidence reported between 2006 and mid 2010 was about 3,000 occurrences in different locations of the Niger Delta.

Oil spillage involves release of dangerous hydrocarbons such as benzene and polynuclear aromatic hydrocarbons into the soil and water sources. The spillage thus pollutes waterways and vast land and affects not only crops but also marine life and water sources for domestic uses. Mangrove forests are predominantly exposed to oil spills since the soils soak up the oil like sponge and release it during raining period. As the spill occurs, it spreads onto farmlands and water bodies. The toxic crude seeps into the grounds and is taken up by the roots of plants. Recent studies have shown that oil spills lower soil fertility and cause poor growth of plants. Decades of oil prospecting and exploitation in the Niger Delta have damaged much of the ecosystem of the region and have caused deterioration of economic, social and political structure in the region. Social tension tends to result from damage claims on environment in the communities. Conflict has become a flourishing business with severe implication for future development prospects (2). The ultimate economic effect of environmental impacts of oil production activities is the catalyst of reduction in the standard of living of people engaging in agricultural and other primary sector activities. The United Nations Human Development Report on the Niger Delta among several alarming declarations on the state of the region's environment asserts that "there is a strong feeling in the region that the degree and rate of degradation are pushing the delta towards ecological disaster" (3). This is buttressed by the results of the research on impact assessment of the 1983 Oshika oil spill by (4) which confirmed the death of floating and submerged aquatic vegetations especially water lettuce, crabs, fish and birds. The economic effects are extensive which include dislocation of traditional economic activities and associated livelihood pursuits as well as danger to human health. The economic effects translate to pecuniary effects, which can be measured in terms of reduced real incomes and the loss of alternative uses of resources consumed by oil companies (5). The pressure on land as a result of pollution caused by oil industry activities also leads to the exploitation of marginal farmlands, overfarming and deforestation, all of which result in a modern wave of environmental degradation. In this way, a kind of vicious circle relationship between environmental degradation and poverty incidence is created, particularly in the face of inappropriate compensation programmes by oil companies, which do not provide for alternative sources of livelihood for deprived land owners. 


\section{Method And Data}

This study is a survey research showing some socio-economic predicaments of the Niger Delta people due to oil companies' activities including oil spillage in this area. The population of the study area consists of 4,500 households out of which the sample of 354 householdswas used. Adopting questionnaire, responses were obtained from the household heads. Two communities in the Niger Delta where oil companies' activities were pervasive were used as the case study. These communities are Burutu and Ogulagha. Only 338 copies of the questionnaires were found to have complete responses among the copies that were returned. In other words, approximately 95 percent of the questionnaires were successfully completed. This was considered to be adequate for the analysis. The relatively high response obtained could be attributed to the direct involvement of the researchers in the administration of the questionnaires.

\section{Discussion Of Findings}

Table Ishowed the income related issues about the respondents. Those that earned regular income were just 18.3 percent of the population. Major occupation of the household heads was farming, representing 65.4 percent. In most cases, the number of persons earning income in a family was one or two. On average, aggregate household income per annum was within the range of \#100000 - \#200000 and above which was less than \$5per day for not less than 50 per cent of the study population. A higher percentage of the population (87.0 per cent precisely) did not pay taxes. The major factors that influenced their income were agriculture, education level and environmental degradation.

TABLE I: Income Related Issues about the Respondents

\begin{tabular}{|c|c|c|}
\hline Description & Frequency & Percentage \\
\hline \multicolumn{3}{|l|}{ Do you earn a regular income? } \\
\hline 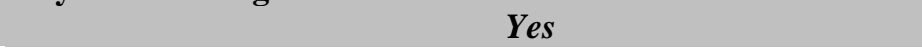 & 62 & 18.3 \\
\hline No & 276 & 81.7 \\
\hline \multicolumn{3}{|l|}{ Whoareyou? } \\
\hline Trader & 97 & 28.7 \\
\hline Farmer & 221 & 65.4 \\
\hline \multirow[t]{3}{*}{ Civil - } & 8 & 2.4 \\
\hline & 12 & 3.6 \\
\hline & & \\
\hline \multicolumn{3}{|l|}{ Number of persons earning in your family: } \\
\hline One & 127 & 37.6 \\
\hline Two & 177 & 52.4 \\
\hline nd above & & \\
\hline & 34 & 10.1 \\
\hline $\begin{array}{l}\text { Aggregate household income per annum: } \\
\qquad \# 51,000-\# 100,000\end{array}$ & 9 & 2.7 \\
\hline \#100,100- \#200,000 & 147 & 43.5 \\
\hline Above \#200,000 & 185 & 53.8 \\
\hline Do you have any outstanding debts? & 232 & 68.6 \\
\hline No & 106 & 31.4 \\
\hline \multicolumn{3}{|l|}{ Cases of outstanding debts: } \\
\hline \#1000- \#10,000 & 49 & 14.5 \\
\hline$\# 11,000-\# 20,000$ & 38 & 11.2 \\
\hline$\# 21,000-\# 50,000$ & 111 & 32.8 \\
\hline$\# 51,000-\# 100,000$ & 26 & 7.7 \\
\hline Above \#100,000 & 8 & 2.4 \\
\hline Not Applicable & 106 & 31.4 \\
\hline \multicolumn{3}{|l|}{ Factors that influenced household income: } \\
\hline Health & 28 & 8.3 \\
\hline Agriculture & & \\
\hline & 146 & 43.2 \\
\hline Education & & \\
\hline & 58 & 17.2 \\
\hline Environmental degradation & 50 & 14.8 \\
\hline Others & 56 & 16.6 \\
\hline
\end{tabular}




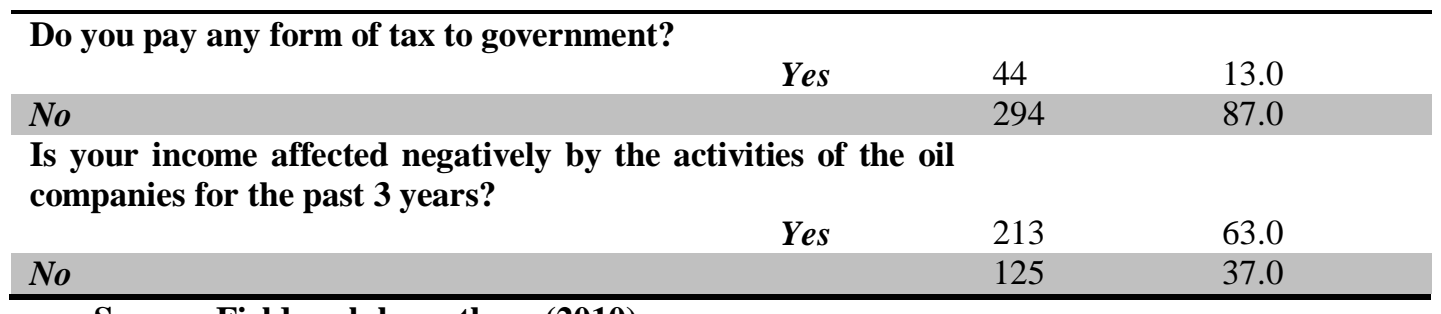

Source: Fieldwork by authors (2010)

The summary of responses on education and skills acquisition matters is provided in table II. It was largelyindicated thus: no high level of illiteracy in the community, adult education is not an essential part of the oil companies' social responsibility programs for poverty reduction, there is scholarship scheme for the youth who are willing to further their education and lack of skill acquisition training programs by oil companies for the young people in the community. These submissions represented an averageresponse of 35.6 and 23.7 percent for disagree and strongly disagree options respectively.

TABLE II: Summary of Response on Education and Skill Acquisition

\begin{tabular}{lcc}
\hline \multicolumn{1}{c}{ Description } & Frequency & Percentage \\
\hline Strongly Agree & 40 & 11.8 \\
Agree & 59 & 17.4 \\
Undecided & 39 & 11.5 \\
Disagree & 120 & 35.6 \\
Strongly Disagree & 80 & 23.7 \\
Total & 338 & 100 \\
\hline
\end{tabular}

Source: Fieldwork by authors (2010)

TABLE III :reveals agricultural sector performance in the community. On average, there was55.6 percent claim that oil exploration affects agricultural output negatively, while the reverse was the position of the remaining 44.5 per cent. Also noted was the continual decline in the agricultural output over time. Largely, annual sale and quality of agricultural products have decreased while the average prices of agricultural products remain constant.

Table III: Agricultural Output Fluctuations

\begin{tabular}{lll}
\hline Description & Frequency & Percentage \\
\hline $\begin{array}{l}\text { Does oil exploration in the area affect agricultural output } \\
\text { positively? }\end{array}$ & \\
$\quad$ No & 188 & 55.6 \\
$\quad$ Yes & 150 & 44.4 \\
What is the trend of agricultural output? & 302 & 89.3 \\
$\quad$ Decrease & 36 & 10.7 \\
$\quad$ Remain the same & & 92.6 \\
How does annual sale of agricultural product behave? & 313 & 7.4 \\
$\quad$ Decrease & 25 & \\
$\quad$ Remain the same & & 44.1 \\
Average price of product behaves in what way? & 149 & 52.7 \\
$\quad$ Increase & 178 & 3.3 \\
$\quad$ Remain the same $\quad 11$ & 78.7 \\
$\quad$ Decrease & & 21.3 \\
\hline How does the average quality of products fluctuate? & 266 & 72 \\
$\quad$ Decrease & & \\
$\quad$ Remain the same & & \\
\hline
\end{tabular}

Source: Fieldwork by authors (2010)

A picture on whether oil companies' presence in the Niger Delta was beneficial or injurious to the people in the community is drawn in table IV. It was largely indicated that oil companies' activities were inimical to social development of the community. Interactions between the companies' staffs and the members of the community was said to be unfriendly. Massive youth unemployment in the community was found.

TABLE IV: Social Related issues

\begin{tabular}{|l|l|l|}
\hline Description & Frequency & Percentage \\
\hline Very good & 11 & 3.3 \\
\hline
\end{tabular}


Perceptions On Socio-Economic Life In Oil Communities Ofniger Delta, Nigeria

\begin{tabular}{|l|l|l|}
\hline Good & 65 & 19.2 \\
\hline Just fair & 43 & 12.7 \\
\hline Injurious & 121 & 35.8 \\
\hline Very injurious & 98 & 29.0 \\
\hline Total & 338 & 100 \\
\hline
\end{tabular}

Source: Fieldwork by authors (2010)

The likely percentage of people in the community that were working in the oil companies located in their area and their status in the companies are pointed out inTable V. Only 9.2 percent of the respondents were working in the oil companies. Those employed from the community were either casual or contract workers and their earnings were just above the minimum wage.

TABLE V: Employment of Indigenes in the Oil Companies

\begin{tabular}{|c|c|c|}
\hline Description & Frequency & Percentage \\
\hline Are you employed in an oil company? & 307 & 90.8 \\
\hline Yes & 31 & 9.2 \\
\hline Not Applicable & 307 & 90.8 \\
\hline Casual Worker & 19 & 5.6 \\
\hline Contract Worker & 12 & 3.6 \\
\hline Nature of Work: & 307 & 90.8 \\
\hline Full Time & 12 & 3.6 \\
\hline Part Time & 19 & 5.6 \\
\hline Monthly Earning Classified: & 307 & 90.8 \\
\hline Bellow \#20000 & 18 & 5.3 \\
\hline Between $\# 21000-\# 60000$ & 13 & 3.8 \\
\hline
\end{tabular}

Source: Fieldwork by authors (2010)

\section{Conclusion}

Government's massive investment in infrastructural development in the Niger Delta is required. One can see the urgent attention needed to stem the tides in the area so as to alleviate the suffering of the masses and foster economic development. Environmental protection and renewal should be issues of priority. The management of the oil companies should be alive to their social responsibilities too. They are expected to be friendlier, raise indigenous employment quotas, assist the governmentnt in providing and financing skills acquisition centers and programs, motivate all levels of staff;support education at all levels and collaborates with government on agricultural development in the area.The loopholes in enforcement of tax payments should be blocked.

\section{References}

[1] Onakuse, S. and E.Lenihan(2007). Policies programmes and sustainable development inNigeria: A critique. Africana: A Journal of Ideas on Africa and the African Diaspora 1(1), 41-58.

[2] Pyagbara, L.S. (2007). The adverse impacts of oil pollution on the environment and wellbeing ofa local indigenous community: The experience of the Ogoni people of Nigeria. A Workshop Organized by United Nations Department of Economic and Social Affairs, Secretariat of the Permanent Forum on Indigenous Issues, Government of Khabarovsk Krai and Russsian Association of Indigenous People of the North, August 27-29.

[3] United Nations Development Program.(2006). Niger Delta Human Development Report, pp. 229.

[4] Powell,G.V.N. and W.B. White (1985). Population trends in some Florida Bay wading birds.

[5] Wilson Bull, 101(3), 436-457.

[6] Orubu, C.O. (2003). Using transportation control measures and economic instruments to reduceair pollution due to automobile emissions.Journal of Social Science, Fourthcoming. 